\title{
SONOGRAPHY OF THE INJURED ULNAR COLLATERAL LIGAMENT OF THE THUMB
}

\author{
KLAUS HERGAN. CHRISTOPH MITTLER \\ From the Landeskrankenhaus, Feldkirch, Austria
}

We used high-resolution ultrasonography to image the ulnar collateral ligament in 39 patients who had sustained recent injuries of the metacarpophalangeal joint of the thumb. All the patients were subsequently operated on and the lesions of the ligament were recorded.

In 36 patients the preoperative ultrasonographic diagnosis was correct. Five of these showed no rupture of the ligament. In the other 31, ultrasonography correctly distinguished between rupture in situ (15) and rupture with dislocation of the ligament (16). Misdiagnosis by ultrasonography in three cases was due to delay of the investigation (three weeks after injury) in one, to technical error in one and to misinterpretation of the image in one.

$J$ Bone Joint Surg [Br] 1995:77-B:77-83.

Received 16 November 1993: Accepted after revision 26 May 1994

Injuries of the ulnar collateral ligament of the thumb (UCL) have been reported many times since the first description by Bunnell in 1948. Campbell (1955) invented the term 'gamekeeper's thumb' to describe the laxity of this ligament which results from the repetitive trauma of killing rabbits. When skiing became a popular winter activity, injuries of the UCL increased dramatically and the term 'skier's thumb' is now in common use (Schultz and Fox 1973: Gerber, Senn and Matter 1981; Massart and Bèzes 1984; Primiano 1985; Fairclough and Mintowt-Czyz 1986).

The metacarpophalangeal joint of the thumb is a hinge joint stabilised by its strong collateral ligaments. The UCL consists of the ulnar collateral ligament proper which lies in the longitudinal axis and of the accessory ulnar collateral ligament which inserts into the volar joint capsule and aponeurosis (Fig. 1). Because of the differential tightness of the two parts during movement, the joint is stable in all positions (Mitzscherling, Päzolt and Stock 1988; Williams et al 1989; Obiltschnig and Klestil 1991; Shaw and Morris 1992).

\footnotetext{
K. Hergan, MD

Central Institute of Radiology

C. Mittler. MD

Department of Traumatology

Landeskrankenhaus Feldkirch. Carinagasse 47, A-68(x) Feldkirch. Austria.

Correspondence should be sent to Dr K. Hergan.
}

(1)1995 British Editorial Society of Bone and Joint Surgery (0301-620X/95/1892\$2.(0)
A particular feature of the joint is the anatomy of the tendon of the adductor pollicis muscle which is also called the adductor aponeurosis. The three sites of insertion of the aponeurosis into the ulnar sesamoid, the base of the proximal phalanx and the extensor aponeurosis counterbalance the pull of the abductors on the proximal phalanx. The UCL is largely covered by this aponeurosis which plays a key part in determining how injuries of the UCL should be treated (Moberg and Stener 1954; Stener 1962; Gerber et al 1981; Hollenburger, Holt and Dax 1982; Pechlaner 1982).

Rupture of the UCL results from an abduction force applied to an already maximally abducted thumb, which can be in the flexed or the extended position (Schultz and



Fig. 1

\begin{abstract}
Anatomy of the metacarpophalangeal joint of the thumb viewed from the ulnar side. 1. proximal phalanx; 2, first metacarpal; 3, ulnar collateral ligament proper; 4, accessory ulnar collateral ligament: 5, proximal palmar ligament; 6 , fibrocartilaginous plate: 7, adductor aponeurosis; 8, adductor pollicis: 9. ulnar sesamoid bone: 10, extensor tendon; 11, tendon of adductor pollicis.
\end{abstract}

Fox 1973; Resnick and Niwayama 1988a,b; Obiltschnig and Klestil 1991) and usually occurs at the distal insertion. Dislocation of the ruptured ligament from beneath the adductor aponeurosis can occur as shown in Figure 2 (Stener 1962; Neviaser, Wilson and Lievano 1971; Bowers and Hurst 1977). This so-called 'Stener lesion' results in chronic instability and later osteoarthritis of the joint.

Some authors have favoured early operation for all ruptures (Moberg and Stener 1954; Cantero, Cruz and Perrenoud 1980; Stothard and Caird 1981; Hollenburger et al 

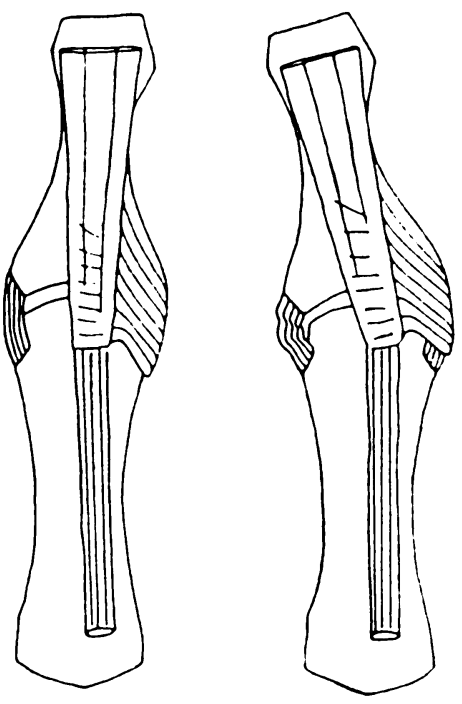

B

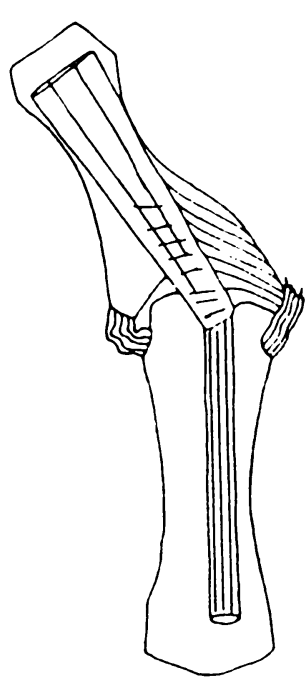

C

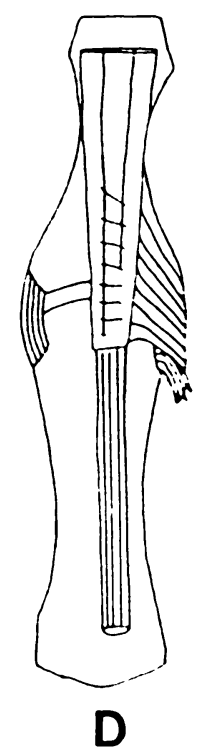

cause of injury was a skiing accident (36), a fall while playing football (1), a fall while mountain climbing (1) and an occupational accident in the forest (1). All the injuries were of the typical extension/abduction type. Radiographs were taken, with and without radial stress, before ultrasonography but the radiographic diagnosis was unknown to the ultrasonographer. All the patients were operated on and a correlation between the ultrasonographic and intraoperative findings was made.

Technique. The examination was performed with a 7.5 MHz linear transducer. The hand is positioned in a water-filled basin, the water serving as an interface between the transducer and the skin to avoid distortion of the soft tissues from compression by the transducer, which is positioned with its long axis in line with the thumb 5 to $10 \mathrm{~mm}$ away from the surface of the skin (Fig. 3). A second plane at right angles to the first can be used to image the adductor

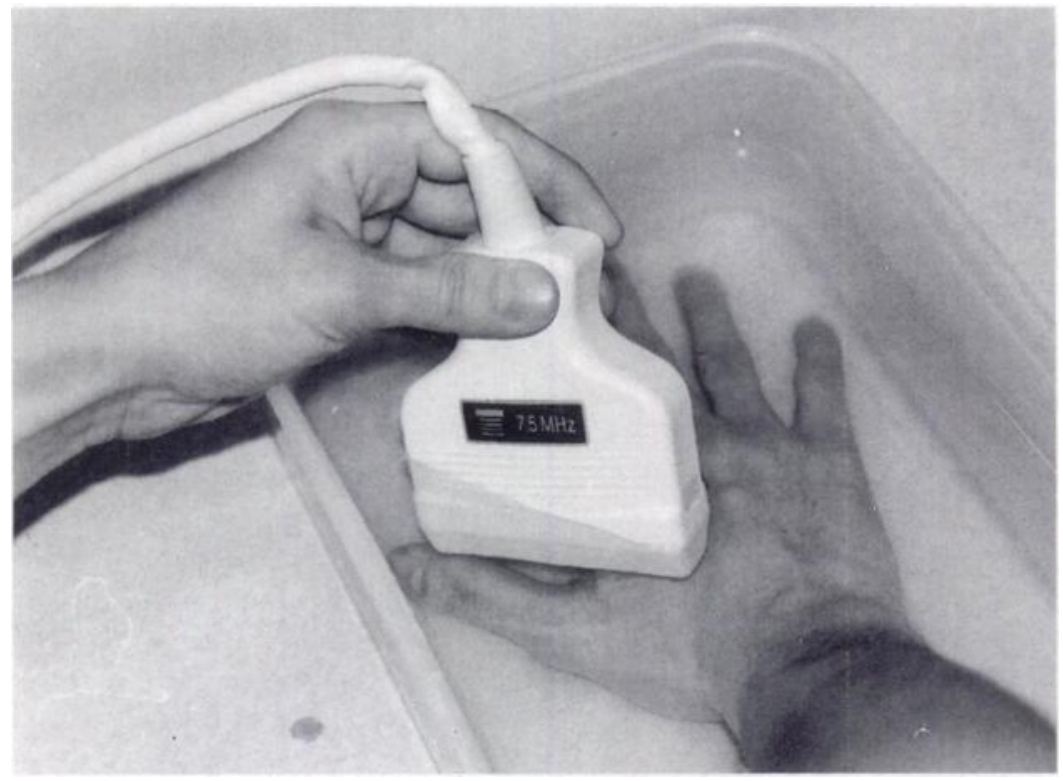

Fig. 3

Longitudinal direction of the transducer in the water-filled basin. 


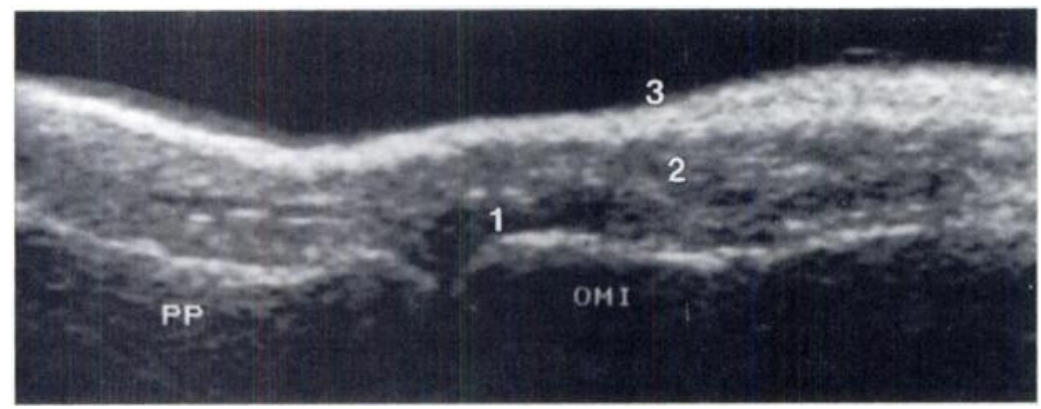



Fig. 4a
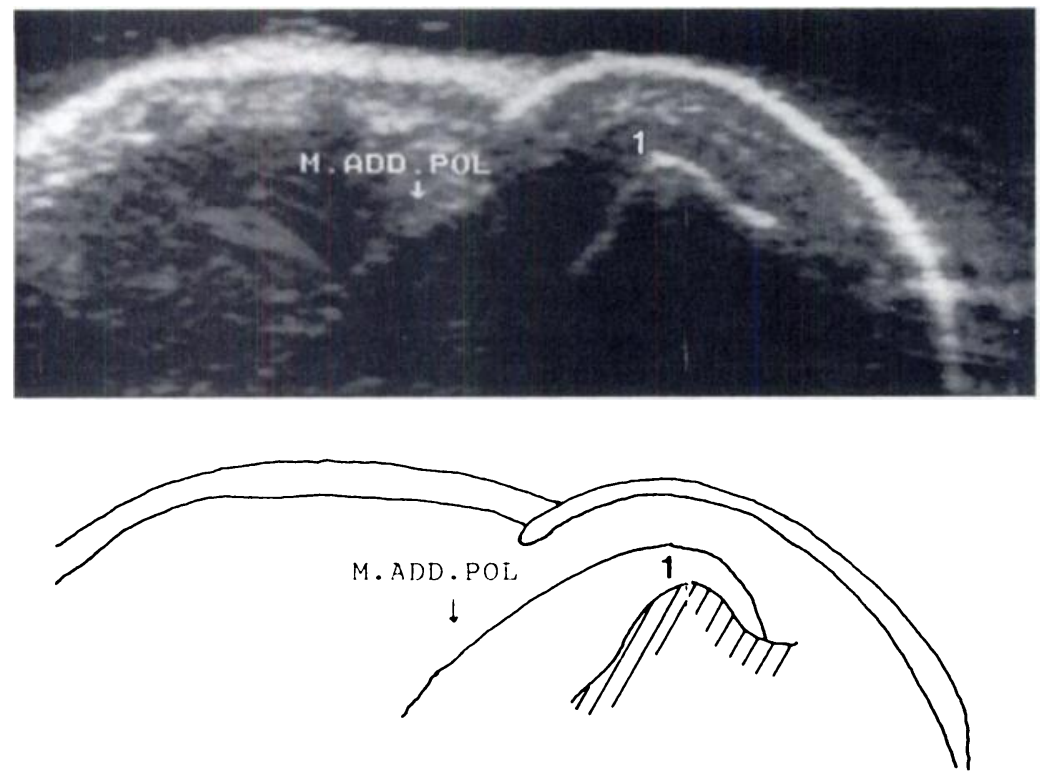

Ultrasonographic anatomy of the ulnar side of a normal first metacarpophalangeal joint. Figure $4 \mathrm{a}-$ Longitudinal plane. PP, proximal phalanx: OMI. first metacarpal: 1, ulnar collateral ligament: 2 . subcutaneous layer: 3, skin. Figure $4 \mathrm{~b}-$ Transverse plane. M.ADD.POL., adductor pollicis: 1, adductor aponeurosis and ulnar collateral ligament.

Fig. 4b

aponeurosis and any traumatic haematoma, but it is not essential for the diagnosis. It can also be of advantage to examine the opposite thumb since the thickness of the UCL varies from patient to patient, but is similar in both hands of the same patient. Artefacts due to hairs, air bubbles and edge phenomena are easily recognised.

With the transducer placed over the ulnar side of the joint it is easy to define the rounded head of the first metacarpal bone and the flat base of the proximal phalanx. The UCL and adductor aponeurosis are demarcated from the echogenic subcutaneous fat as an echolucent band, which runs from the neck of the metacarpal to the base of the phalanx in a convex, curved course (Fig. 4a). With the transducer in the transverse position the echolucent muscle belly of the adductor pollicis can be seen close to the joint line merging into the adductor aponeurosis and UCL (Fig. $4 b)$.

\section{RESULTS}

At operation the UCL was found to be dislocated from beneath the adductor aponeurosis in 18 patients and was in situ in 21 . The sonographic diagnosis was the same as the intraoperative diagnosis in 36 of the 39 patients (92\%). In two patients a dislocated ruptured UCL was diagnosed sonographically as a rupture in situ; in one a rupture in situ 
was diagnosed sonographically as dislocated. The specifcity of the examination was therefore $89 \%$ for dislocated ruptures and $95 \%$ for those in situ.

One of the wrongly diagnosed patients was not examined until three weeks after the accident when ultrasonography showed a large ill-defined echolucent area at the joint level which was misinterpreted as repair tissue around a rupture in situ. The presence of scar tissue was confirmed intraoperatively, but the ligament was found to be dislocated and already considerably shrunken (see Fig. 7).

The second wrongly diagnosed patient had been examined with the transducer pressed against the skin and the consequent distortion of the tissues caused the misinterpretation of a dislocated ligament as rupture in situ.

In the third patient the diagnosis was wrong because two echolucent zones were detected, one close to the articular space and the second at the neck of the metacarpal. This picture was interpreted as a dislocation of the ligament, but a rupture in situ was found at operation.

In one patient the ligament was torn at its proximal insertion on the metacarpal. Ultrasonography correctly diagnosed a rupture in situ but did not correctly locate the site of the tear.

In five patients the clinical picture suggested an injury of the UCL, but there was no evidence of subluxation on ultrasonography. The ligament was in its normal position, and no haematoma could be found, but the skin and subcutaneous tissues were oedematous. This appearance was interpreted as a strain and at surgery no ligament rupture was found.

\section{DISCUSSION}

Although Stener (1962) and some other authors (Gerber et al 1981; Lamb and Angarita 1985; Louis et al 1986) were of the opinion that tears of the UCL could only be defined intraoperatively, others have developed several methods for preoperative diagnosis. Van Wetter (1986) used his rubberband test to verify a torn ligament, and others used stressed radiographs with or without specially-developed holding devices (Schultz and Fox 1973: Heim 1982; Pechlaner 1982; Curtis and Downey 1983; Rubach and Paar 1983; Downey and Curtis 1986; Lütten. Thomas and Dihlmann 1987). None of these methods, however, allowed differentiation between dislocated ruptures and ruptures in situ. Moutet et al (1989) and Abrahamsson et al (1990) tried to determine those with the Stener lesion by palpation and advocated different treatments for the two types.

Arthrography can differentiate a simple rupture of the articular capsule from a capsuloligamentous rupture (Engel et al 1979; Stothard and Caird 1981), and Bowers and Hurst (1977) reported that it was possible to define the exact position of the torn ligament. Resnick and Danzig (1976) and Resnick and Niwayama (1988a,b) recommended radiography with and without stress complemented by arthrography. Arthroscopy is an accurate method of diagnosis (Vaupel and Andrews 1985) but it has not gained wide acceptance because of its invasiveness.

In contrast to radiological methods ultrasonography can image soft tissues due to differences in their impedance. We have defined the following sonographic criteria for rupture of the UCL:

1) Broadening and fading of the echogenic band which represents the skin layer.

2) Broadening and echolucent appearance of the subcutaneous layer.

3) Subluxation of the metacarpophalangeal joint with radial deviation of the proximal phalanx. This is a definite sign of capsuloligamentous rupture.

4) If the torn UCL is in situ the normal convex course of the echolucent ligament is present (Fig. 5).

5) If the torn UCL is dislocated there is an echolucent bulge
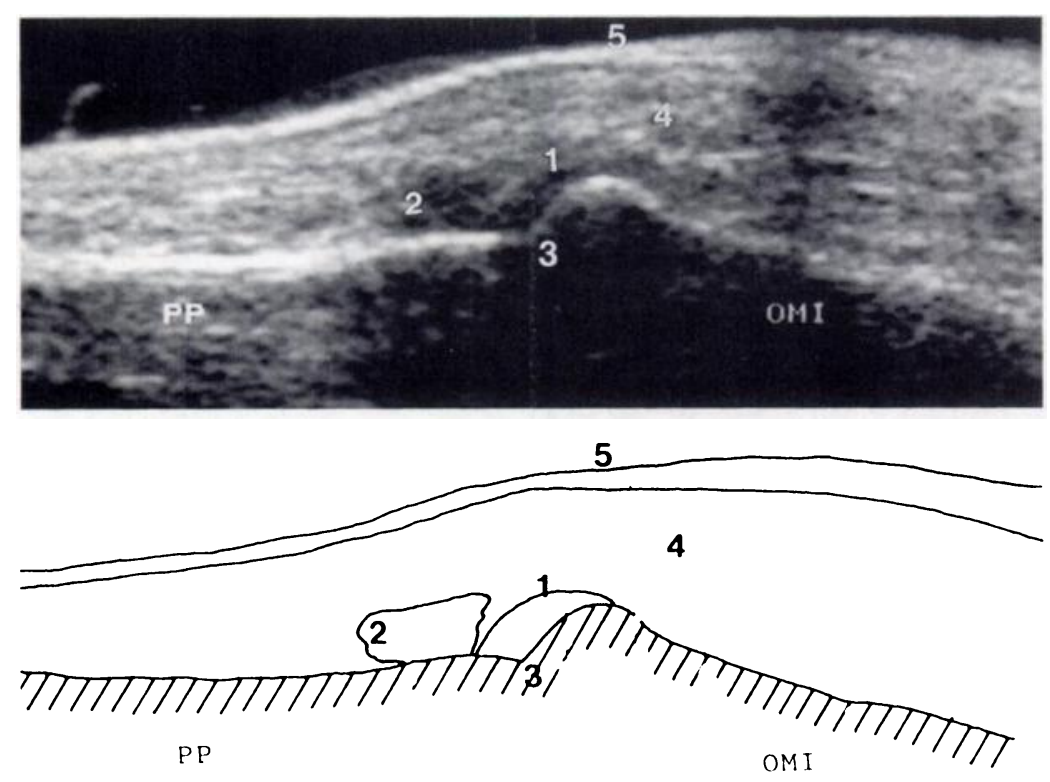

Fig. 5

Rupture in situ of the ulnar collateral ligament (right thumb). PP. proximal phalanx: OMI. tirst metacarpal: 1. ulnar collateral ligament in situ: 2. small haematoma: 3, widened joint space: 4 . subcutaneous layer: 5. skin. 

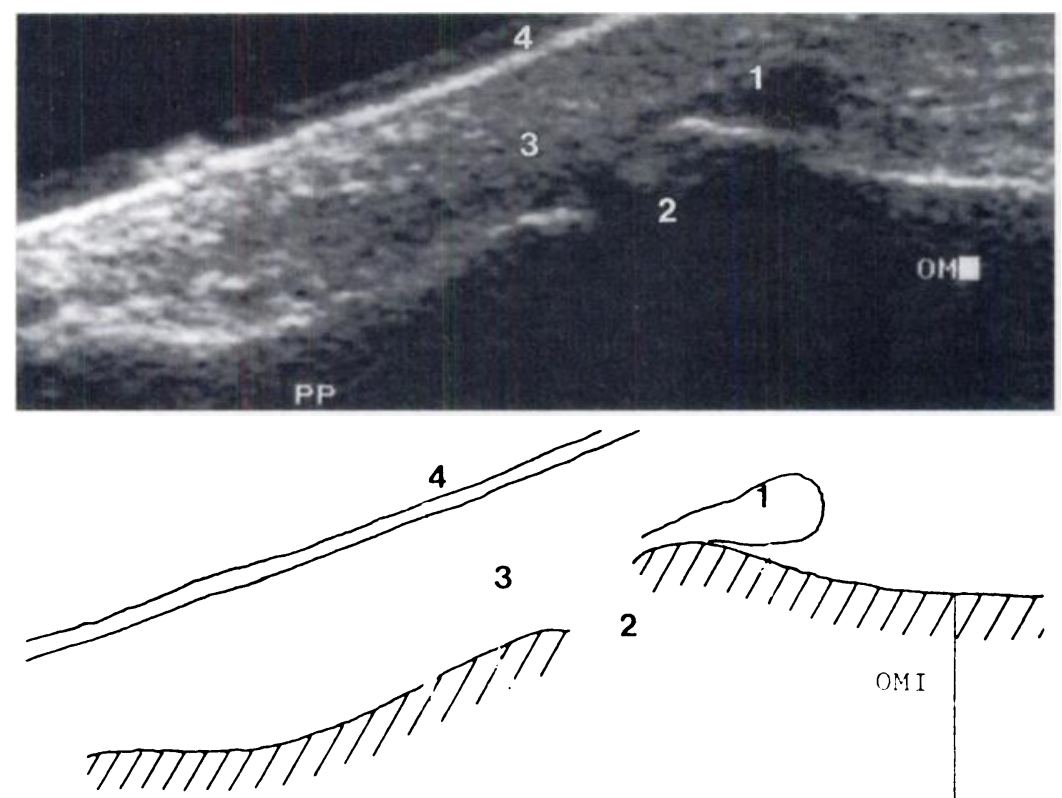

PP

at the neck of the metacarpal bone and loss of the convex echolucent image of the ligament (Fig. 6).

6) In cases of recent injury, haematoma is represented by a 5 to $10 \mathrm{~mm}$ thick, spherical echolucent structure in the immediate vicinity of the torn UCL, its location depending on the site of rupture.

7) If more than one week has elapsed since injury the haematoma cannot be detected and may be replaced by a diffuse echolucent, non-homogeneous image of scar tissue (Fig. 7).

The presence of the small haematoma is strong confirma- tion of the diagnosis of a ligament rupture. We cannot explain why the haematoma is found usually at the long end of the torn ligament or why it is sometimes absent. It should not be confused with an effusion within the intact joint capsule which is always closer to the head of the metacarpal.

A radiograph of the injured thumb is always needed to exclude bone lesions (Kjaer-Petersen, Andersen and Langhoff 1991) but the need for stressed radiographs can be eliminated by ultrasonography. This avoids any risk of secondary dislocation (Obiltschnig and Klestil 1991)


Fig. 7

Ruptured ulnar collateral ligament with scar formation three weeks after injury (right thumb). PP, proximal phalanx: OMI, first metacarpal; 1, scar formation: 2, widened joint space; 3, subcutaneous layer; 4 , skin. 


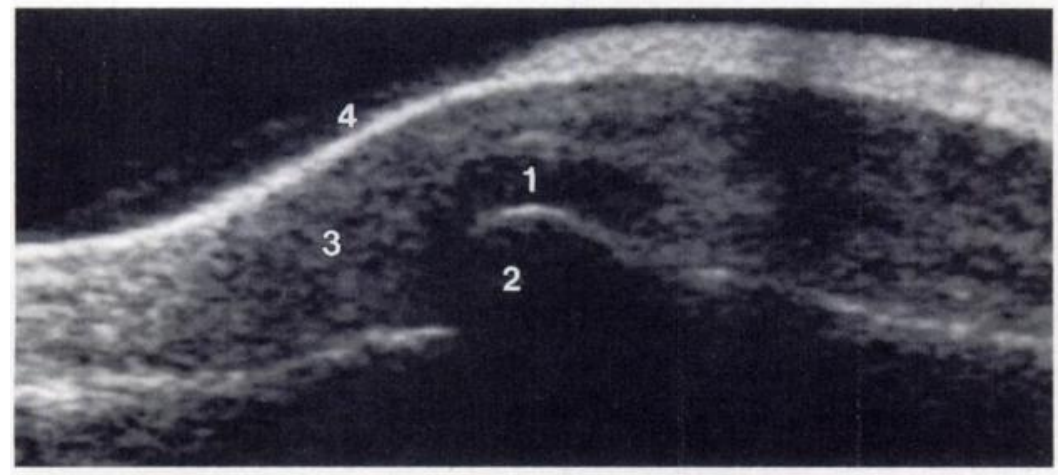

Fig. $8 \mathrm{a}$

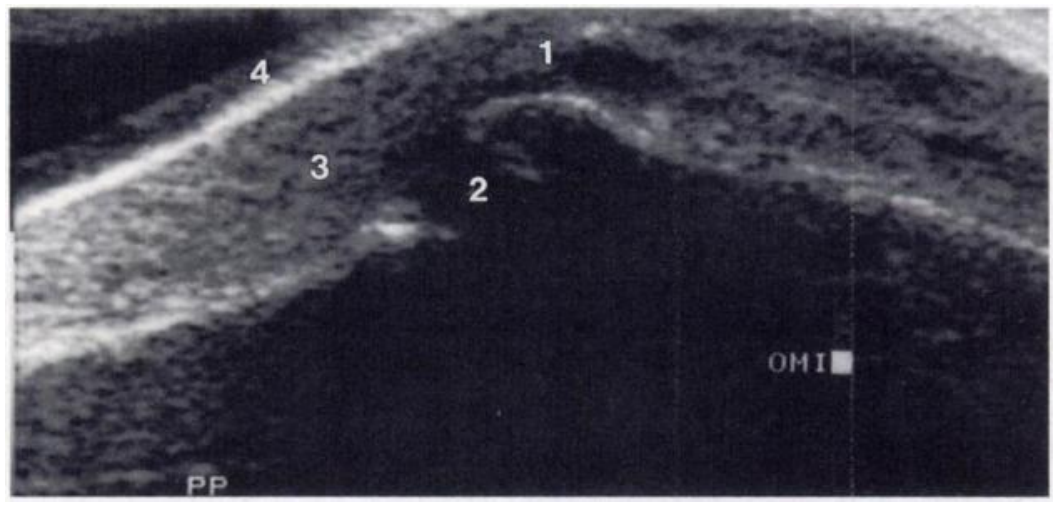

Fig. $8 b$

although Abrahamsson et al (1990) have denied that this can happen. MRI may be an alternative to ultrasonography as it can provide accurate images of the soft tissues (Fry et al 1991; Spaeth et al 1993; Louis and Buckwalter 1989).

Several different treatments have been proposed for the various patterns of UCL rupture (Pechlaner 1982; Paar and Rubach 1983; Louis et al 1986; Vanclooster et al 1988; Bonaga, Danda and Fama 1989; Moutet et al 1989). As ultrasonography proves its worth it will be possible to classify the injuries in a high proportion of cases and to give the appropriate treatment. Ruptures in situ could be treated conservatively and those with a Stener lesion would need surgical reconstruction (Paar and Rubach 1983; Mitzscherling et al 1988; Moutet et al 1989; Abrahamsson et al 1990). Obiltschnig and Klestil (1991), however, suggested that even when the ligament is ruptured in situ there is no contact between the ends of the ligament. As healing is made impossible by constant movement, immobilisation of the metacarpophalangeal joint in a glove spica cast is thought to be mandatory even for tears in situ (Campbell et al 1992).

Dislocated torn ligaments, displaced avulsion fractures, the rare atypical dislocations and cases of epiphysiolysis all require early surgical treatment to restore full function (Winslet, Clarke and Mulligan 1986; White 1986; Onuba and Essiet 1987; Reck et al 1991: Sartorius et al 1991). Late operations have a bad prognosis because retraction and atrophy of the ligament make its reconstruction almost impossible (Neviaser et al 1971; Reikeras and Kvarnes
Two patients with torn ulnar collateral ligaments in different positions. Figure $8_{a}$ - Rupture in situ (right thumb). 1, ulnar collateral ligament in situ: 2. widened joint space: 3. subcutaneous layer; 4, skin. Figure $8 \mathrm{~b}$ - Dislocated rupture. PP, proximal phalanx: OMI, first metacarpal: 1 . dislocated ligament with small haematoma: 2, widened joint space; 3 , subcutaneous layer: 4 , skin.
1982; Brückner 1985; Helm 1987: Sennwald, Segmüller and Egli 1987; Arnold, Cooney and Wood 1992).

Conclusions. The advantages of ultrasonography are its high precision in identifying ruptures of the ligament and in differentiating ruptures in situ from those with the Stener lesion (Fig. 8). The examination is quick, cheap, widely available and painless. The disadvantage is that, like all ultrasonographic examinations, its accuracy depends on the proficiency of the examiner.

No benefits in any form have been received or will be received from a commercial party related directly or indirectly to the subject of this article.

\section{REFERENCES}

Abrahamsson SO, Sollerman C, Lundborg G, et al. Diagnosis of displaced ulnar collateral ligament of the metacarpophalangeal joint of the thumb. J Hand Surg [Am] 1990:15:457-60.

Arnold DM, Cooney WP, Wood MB. Surgical management of chronic ulnar collateral ligament insufficiency of the thumb metacarpophalangeal joint. Orthop Rev 1992:21:583-8.

Bonaga S, Danda F, Fama G. Le lesioni del comparto legamentoso ulnare della metacarpo-falangea del pollice: studio anatomico e classificazione. Chir Organi Mov' 1989:74:51-5.

Bowers WH, Hurst LC. Gamekeeper's thumb: evaluation by arthrography and stress roentgenography. J Bome Joint Surg $[\mathrm{Am}]$ 1977:59-A:519-24.

Brückner H. Zur operativen Behandlung veralteter ulnarer Seitenbandrupturen des Daumengrundgelenkes mit der Sandwich-Methode. Zentralbl Chir 1985:110:442-5.

Bunnell S. Surgery of the hand. 2nd ed. Philadelphia. etc: Lippincott. 1948.

Campbell CS. Gamekeeper's thumb. J Bone Joint Surg $|\mathrm{Br}|$ 1955:37-B:148-9. 
Campbell JD, Feagin JA, King P, et al. Ulnar collateral ligament injury of the thumb: treatment with glove spica cast. Am J Sports Med 1992:20:29-30.

Cantero J, Cruz M, Perrenoud L. Recent capsulo-ligamentary lesions of the metacarpophalangeal joint of the thumb. Ann Chir 1980:34:655-62.

Curtis DJ, Downey EF Jr. A simple first metacarpophalangeal stress test. Radiology 1983:148:855- 6 .

Downey EF, Curtis DJ. Patient-induced stress test of the first metacarpophalangeal joint: a radiographic assessment of collateral ligament injuries. Radiology 1986;158:679-83.

Engel J, Ganel A, Ditzian R, Militoanu J. Arthrography as a method of diagnosing tear of the ulnar collateral ligament of the metacarpophalangeal joint of the thumb ('gamekeeper's thumb'). J Trauma 1979:19:106-9.

Fairclough JA, Mintowt-Czyz WJ. Skier's thumb: a method of prevention. Injury 1986:17:203-4.

Fry ME, Jacoby RK, Hutton CW, et al. High-resolution magnetic resonance imaging of the interphalangeal joints of the hand. Skeletal Radiol 1991:20:273-7.

Gerber C, Senn E, Matter P. Skier`s thumb: surgical treatment of recent injuries to the ulnar collateral ligament of the thumb's metacarpophalangeal joint. Am J Sports Med 1981;9:171-7.

Heim U. Simultaneous functional bilateral radiographs of the metacarpophalangeal joint of the thumb in hyper-pronation. Ann Chir Main 1982:1:183-6.

Helm RH. Hand function after injuries to the collateral ligaments of the metacarpophalangeal joint of the thumb. $J$ Hand Surg $[B r]$ 1987:12:252-5

Hollenburger G, Holt R, Dax H. Der frische Skidaumen: Entstehung, Häufigkeit und Behandlung nach Krankengut eines mittleren Krankenhauses im Shigebiet. Med Welt 1982:33:45-7.

Kjaer-Petersen K, Andersen K, Langhoff $O$. Combined basal metacarpal fracture and ligament injury of the metacarpophalangeal joint of the thumb. J Bone Joint Surg [Br] 1991:73-B:176-7.

Lamb DW, Angarita G. Ulnar instability of the metacarpophalangeal joint of the thumb. $J$ Hand Surg $[B r]$ 1985:10:113-4.

Louis DS, Buckwalter KA. Magnetic resonance imaging of the collateral ligaments of the thumb. J Hand Surg [Am] 1989;14:739-41.

Louis DS, Huebner JJ, Hankin FM. Rupture and displacement of the ulnar collateral ligament of the metacarpophalangeal joint of the thumb: preoperative diagnosis. $J$ Bone Joint Surg $[\mathrm{Am}]$ 1986;68-A:1320-6.

Lütten C, Thomas W, Dihlmann W. Haltegerät zum standardisierten röntgenologischen Nachweis von ulnaren, volaren und radialen Kapsel-Bandläsionen am Daumengrundgelenk. Radiologe 1987;27:273-8.

Massart P, Bèzes H. Severe metacarpophalangeal sprain of the thumb in ski accidents. Ann Chir Main 1984:3:101-12.

Mitzscherling CP, Päzolt HJ, Stock A. Bandverletzungen des Daumengrundgelenks. Zentralbl Chir 1988:113:1263-7.

Moberg E, Stener B. Injuries to the ligaments of the thumb and fingers: diagnosis, treatment and prognosis. Acta Chir Scand 1953-54:106:166-86

Moutet F, Guinard D, Lebrun C, et al. Metacarpophalangeal thumb sprains based on experience with more than 1000 cases. Ann Chir Main 1989:8:99-109.

Neviaser RJ, Wilson JN, Lievano A. Rupture of the ulnar collateral ligament of the thumb (gamekeeper's thumb): correction by dynamic repair. J Bone Joint Surg [Am] 1971;53-A:1357-64.

Obiltschnig A, Klestil T. Frische ulnare Kapsel-Band-Verletzungen am Daumengrundgelenk. Unfallchirurgie 1991:17:39-43.
Onuba O, Essiet A. Irreducible dislocation of the metacarpophalangeal joint of the thumb due to tendon interposition. J Hand Surg $|\mathrm{Br}|$ 1987;12:60-1.

Paar O, Rubach A. Die Rekonstruktion frischer und alter Bandverletzungen am Daumengrundgelenk. Akt Traumatol 1983:13:88-92.

Pechlaner S. Zur Verletzung des ulnaren Bandapparates des Daumengrundgelenkes. Aktuel Traumatol 1982:12:210-4.

Primiano GA. Skier's thumb injuries associated with flared ski pole handles. Am J Sports Med 1985:13:425-7.

Reck T, Landsleitner B, Richter H, Geldmacher J. Eine neue Methode der transossären Ausziehdrahtfixation bei Bandverletzungen am Daumengrundgelenk. Handchir Mikrochir Plast Chir 1991:23:90-2.

Reikeras O, Kvarnes L. Rupture of the ulnar ligament of the metacarpophalangeal joint of the thumb. Arch Orthop Trauma Surg 1982;100:175-7.

Resnick D, Danzig LA. Arthrographic evaluation of injuries of the first metacarpophalangeal joint: gamekeeper's thumb. Am J Roentgenol 1976:126:1046-52.

Resnick D, Niwayama G. Diagnosis of bone and joint disease. Vol. I. 2nd ed. Philadelphia, etc: WB Saunders Company, 1988a:328-9.

Resnick D, Niwayama G. Diagnosis of bone and joint disease. Vol. 6 , 2nd ed. Philadelphia, etc: WB Saunders Company, 1988b:2876-86.

Rubach A, Paar O. Die standardisierte Röntgenuntersuchung bei frischen und alten Kapselbandverletzungen des Daumengrundgelenks. Chirug 1983:54:423-4.

Sartorius C, Darmon C, Robert O, et al. Luxation palmaire irrèductible de la métacarpo-phalangienne du pouce par accident de ski. Ann Chir Main Memb Super 1991;10:458- 62.

Schultz RJ, Fox JM. Gamekeeper's thumb: result of skiing injuries. $N Y$ State J Med 1973;73:2329-31.

Sennwald G, Segmüller G, Egli A. The late reconstruction of the ligament of the metacarpo-phalangeal joint of the thumb. Ann Chir Main 1987;6:15-24

Shaw SJ, Morris MA. The range of motion of the metacarpophalangeal joint of the thumb and its relationship to injury. J Hand Surg $[\mathrm{Br}]$ 1992;17:164-6.

Spaeth HJ, Abrams RA, Bock GW, et al. Gamekeeper thumb: differentiation of nondisplaced and displaced tears of the ulnar collateral ligament with MR-imaging work in progress. Radiology 1993:188:553-6.

Stener B. Displacement of the ruptured collateral ligament of the metacarpo-phalangeal joint of the thumb: a clinical and anatomical study. $J$ Bone Joint Surg $[\mathrm{Br}$ l 1962:44-B:869-79.

Stothard J, Caird DM. Experience with arthrography of the first metacarpophalangeal joint. Hand 1981:13:257-66.

van Wetter P. Diagnosis of rupture of the ulnar collateral ligament of the metacarpophalangeal joint of the thumb: presentation of a simple clinical and radiological test. Ann Chir Main 1986:5:135-8.

Vanclooster P, Reinders J, Lens J, et al. Rupture of the ulnar, collateral ligament of the metacarpophalangeal joint of the thumb, so-called 'wobbly thumb'. Acta Chir Belg 1988;88:51-4.

Vaupel GL, Andrews JR. Diagnostic and operative arthroscopy of the thumb metacarpophalangeal joint: a case report. Am J Sports Med 1985:13:139-41.

White GM. Ligamentous avulsion of the ulnar collateral ligament of the thumb of a child. $J$ Hand Surg [Am] 1986;11:669-72.

Williams PL, Warwick R, Dyson M, Bannister LH. Gray's Anatomy: 37th ed. Edinburgh, etc: Churchill Livingstone, 1989:435.

Winslet MC, Clarke NM, Mulligan PJ. Breakdancer's thumb: partial rupture of the ulnar collateral ligament with a fracture of the proximal phalanx of the thumb. Injury 1986:17:201-2. 